University of Nebraska - Lincoln

DigitalCommons@University of Nebraska - Lincoln

Entomology Papers from Other Sources

Entomology Collections, Miscellaneous

2003

\title{
Kairomonal effect of walking traces from Euschistus heros (Heteroptera: Pentatomidae) on two strains of Telenomus podisi (Hymenoptera: Scelionidae)
}

\author{
Miguel Borges \\ USDA-ARS \\ Stefano Colazza \\ USDA-ARS \\ Pamela Ramirez-Lucas \\ USDA-ARS \\ Kamlesh R. Chauhan \\ USDA-ARS \\ Maria Carolina Blassioli Moraes \\ Embrapa Genetic Resources and Biotechnology \\ See next page for additional authors \\ Follow this and additional works at: https://digitalcommons.unl.edu/entomologyother \\ Part of the Entomology Commons
}

Borges, Miguel; Colazza, Stefano; Ramirez-Lucas, Pamela; Chauhan, Kamlesh R.; Blassioli Moraes, Maria Carolina; and Aldrich, Jeffrey Richard, "Kairomonal effect of walking traces from Euschistus heros (Heteroptera: Pentatomidae) on two strains of Telenomus podisi (Hymenoptera: Scelionidae)" (2003). Entomology Papers from Other Sources. 6.

https://digitalcommons.unl.edu/entomologyother/6

This Article is brought to you for free and open access by the Entomology Collections, Miscellaneous at DigitalCommons@University of Nebraska - Lincoln. It has been accepted for inclusion in Entomology Papers from Other Sources by an authorized administrator of DigitalCommons@University of Nebraska - Lincoln. 


\section{Authors}

Miguel Borges, Stefano Colazza, Pamela Ramirez-Lucas, Kamlesh R. Chauhan, Maria Carolina Blassioli Moraes, and Jeffrey Richard Aldrich 


\title{
Kairomonal effect of walking traces from Euschistus heros (Heteroptera: Pentatomidae) on two strains of Telenomus podisi (Hymenoptera: Scelionidae)
}

\author{
MIGUEL BORGES*†, STEFANO COLAZZA* \\ RA M I R E - L UCAS*, , K A M L ESH R. CHAUHA N*, MARIA \\ CAROLINA B L A S I O L I M RAES † and JEFFREY R I H A R
} A L D R I C H *

*USDA-ARS, Chemicals Affecting Insect Behaviour Laboratory, Agricultural Research Center-West, Beltsville, Maryland, U.S.A., †Embrapa Genetic Resources and Biotechnology, SAIN, Parque Estação Biológica, Brasília, Brazil, †S.En.Fi.Mi.Zo. Department - Section of Entomology, Acarology and Zoology, University of Palermo, Palermo, Italy and $\$ 33$ Rue de Plougastel, Montigny-le-Bretonneux, France

\begin{abstract}
The semiochemical cues used by geographically isolated strains of the parasitoid, Telenomus podisi (Ashmed), to find eggs of the stink bug Euschistus heros were investigated. Two strains of Te. podisi, maintained on eggs of a South American host (E. heros) were studied. One parasitoid strain originated from specimens collected near Brasilia, Brazil (SA strain), and a second strain originated from specimens collected at Beltsville, Maryland (NA strain). Cold tolerance tests of adults from the NA and SA Te. podisi strains, analyses of the cuticular hydrocarbons between the two strains, and crossing experiments between strains each indicated consistent differences between the NA and SA strains. Subsequent experiments using E. heros showed that SA Te. podisi females specifically recognize traces left on the substrate by walking $E$. heros females and then search intensively the area of the 'footprints', apparently looking for an egg mass to parasitize. By contrast, Te. podisi females of the NA strain are incapable of recognizing the footprints of $E$. heros females despite the fact that these parasitoids were reared from eggs of E. heros. The possibility that the two strains are actually different species is discussed.
\end{abstract}

Key words. Behaviour, biological control, cold tolerance, cuticular hydrocarbons, egg parasitoid, kairomone, neotropical brown stink bug.

\section{Introduction}

Intraspecific variability in biological or behavioural traits of entomophagous parasitoids is important for their efficacy in biological control and has implications for biosystematics (Ruberson et al., 1989; Lewis et al., 1990).

Correspondence: Dr Miguel Borges, EMBRAPA-Genetic Resources and Biotechnology, Parque Estação Biológica, Cx. Postal 02372, 70849-970 Brasilia DF, Brazil. Tel: +55 61448 4683; fax: +55 61340 3624; e-mail: mborges@cenargen.embrapa.br
The subject of the present investigation, the egg parasitoid Telenomus podisi (Ashmed), was shown in laboratory bioassays to recognize its host, Euschistus heros (F.), through both chemical and physical cues (Borges etal., 1999). In addition, the diel periodicity of the egg parasitoids matches that of their host, E. heros (Borges et al., 1998). The importance of chemical stimuli for the orientation of female egg parasitoids toward their hosts has been documented for many species (Vinson, 1998). Frequently, long-range attraction is first mediated by host-plant volatiles and/or volatiles emanating from hosts. For example, in the Heteroptera, Leal et al. (1995) showed that the egg parasitoid, Ooencyrtus 
nezarae (Hymenoptera: Encyrtidae), utilizes the attractant pheromone of the bean bug, Riptortus clavatus (Alydidae), to locate habitat likely to harbour eggs of this potential host. Trissolcus basalis (Hymenoptera: Scelionidae), an egg parasitoid of the stink bug, Nezara viridula, homes-in on (E)-2-decenal from the defensive metathoracic gland of N. viridula (Mattiacci et al., 1993). In the case of Te.podisi, the male-produced pheromone of E. heros is apparently attractive to the wasps at long-distance (Borges et al., 1998). Other substances, usually associated directly with the host and often less volatile than long-range cues, are exploited by parasitoids at close-range for host finding and host-recognition (Vinson, 1998; Boo \& Yang, 2000). For example, Colazza etal. (1999) showed that Tr. basalis females remain longer and search more intensively for host eggs in an area where traces have been left on the substrate by walking $N$. viridula adults. Similarly, two strains of the lepidopteran egg parasitoid Telenomus busseolae are stimulated to search in areas contaminated by hosts as reported by Colazza \& Rosi (2001).

The genus Telenomus includes a large number of species and involves a wide range of variation, making a revision at the generic level difficult even for a single biogeographical region. For example, in the Nearctic's domain, there may be more than 200 species (Johnson, 1984). Johnson (1992) considered $T e$. podisi, in particular, to be a highly variable species, especially in the tropics, and even in the temperate region, Ehler (2000) reported two forms of Te. podisi based on differences in colouration of the antennal radicle of this species. Studies of Neotropical scelionids using molecular markers reveal considerable variability even among members of the same species (Aljanabi et al., 1998).

The variability among species or even among strains of a species is very important for biological control efforts, both classical and augmentative. For example, attempts to use strains of parasitoids maladapted to local climates or with inferior host searching properties often results in biocontrol failures (Parra et al., 2002).

In the present study, the response of two geographically isolated strains of Te. podisi to the semiochemical cues used in the location of the eggs of the stink bug E. heros was investigated. The behavioural responses of two Te. podisi strains, one from South America and one from North America, to stimuli emanating from E. heros originating from Brazil were compared. In addition, the cuticular hydrocarbon profiles of the two parasitoid strains were examined, and the cold tolerance of adults from each strain was tested.

\section{Materials and methods}

\section{Parasitoids}

The North American (TpNA) strain of Te podisi originated from individuals that emerged from Euschistus obscurus eggs placed in the field at the Beltsville Agricultural Research Center (BARC), Maryland $\left(39^{\circ} 2^{\prime} \mathrm{N} / 76^{\circ} 55^{\prime} \mathrm{W}\right)$, in
2000 (Aldrich etal., 1994; Borges \& Aldrich, 1994). The South American (TpSA) strain of Te. Podisi originated from a colony started from eggs imported from a colony maintained at EMBRAPA Genetic Resources and Biotechnology laboratory in Brazilia, DF, Brazil since 1996 from specimens field-collected in Brazil, near Brasilia $\left(15^{\circ} 47^{\prime} \mathrm{S}\right.$ and $\left.47^{\circ} 55 \mathrm{~W}\right)$ from parasitized $E$. heros eggs. Both parasitoid strains were maintained in the laboratory on $E$. heros eggs. Fresh egg masses (approximately 200 eggs; $\leq 24$ h) were glued to a strip of cardboard with honey and then placed in a $15-\mathrm{mL}$ glass test tube plugged with cotton. Eight females and three males were introduced into each glass tube for mating and for egg parasitism, and held in a growth chamber at $25 \pm 2{ }^{\circ} \mathrm{C}, 75 \pm 5 \% \mathrm{RH}$ in a LD $16: 8 \mathrm{~h}$ photoperiod.

Hosts

The BARC E. heros colony was started from eggs imported from a colony maintained in the Brasilia laboratory since 1996 from specimens field-collected in Brazil, near Brasilia. The bugs were reared in 5-L plastic containers on sunflower seeds, peanuts, fresh green beans and water, renewed three times a week (Aldrich et al., 1994). A paper towel was placed inside against the wall of each container as an oviposition substrate and shelter for the bugs. Egg masses were collected daily and incubated in Petri dishes until emergence of second instars, at which time nymphs were transferred to plastic containers and reared as above.

Female E. heros require approximately 2 weeks after ecdysis to the adult stage to become sexually mature (Aldrich et al., 1994; Borges \& Aldrich, 1994). Ovipositional and preovipositional-mated females were used for the bioassays, but the latter group consisted of females $2-3$ days after mating prior to egg laying. Under the laboratory conditions described here, E. heros females began laying eggs after the fourth day following mating. Female stink bugs used for all experiments were 2-4 weeks old.

\section{Crossing experiments}

Cross mating tests were carried out to check whether or not the two parasitoid strains belonged to the same species. Reciprocal and nonreciprocal (control) crosses between the two strains of Te. podisi comprised: (i) introduction of a virgin adult female from one strain into a glass tube containing an adult male of the other strain; (ii) introduction of one E. heros egg parasitized by a virgin female Te. podisi of one strain into a glass tube containing an egg parasitized by a mated female $T e$. podisi of the other strain; or (iii) introduction of a virgin adult female of one strain into a glass tube containing an adult male of the same strain (control).

Virgin Te. podisi pairs, 1-2 days old, of both treatment combinations were confined for approximately $48 \mathrm{~h}$ in a test tube to allow copulation. After $48 \mathrm{~h}$, individual females were then placed in a tube with approximately 20 unparasitized E. heros eggs. After $24 \mathrm{~h}$, the egg masses were 
removed and stored individually until offspring emerged. The crosses were evaluated indirectly by counting the pairs that produced female offspring because this species has haplodiploid sex determination. Each cross was replicated at least 10 times.

From the control crossing experiments of the abovedescribed procedure, data from the development time and sex ratio of the two Te. podisi strains were also recorded for further statistical analysis.

\section{Freezing experiments}

Adult egg parasitoids; 5-6 days old, of both sexes and from each strain were held at $-4{ }^{\circ} \mathrm{C}$ for $24,48,72,96,120$ and $144 \mathrm{~h}$. After the prescribed cold treatment, the wasps were warmed to ambient temperature for $24 \mathrm{~h}$, and the number of insects that recovered from the freezing state was recorded. Each time period treatment was replicated at least five times.

\section{Cuticular hydrocarbon analysis}

Adult male and female parasitic wasps of the two $T e$. podisi strains (40 adults per sample) were extracted in $2 \mathrm{~mL}$ screw-top vials containing $1 \mathrm{~mL}$ of $n$-heptanes (high-performance liquid chromatography grade, Aldrich Chemical Co., Milwaukee, WI). After $3 \mathrm{~min}$, the $n$-heptane extract was filtered and collected in $1 \mathrm{~mL}$ screw top graduated conical vials, and concentrated to $100 \mu \mathrm{L}$ under a flow of argon. One microliter of each extract was analysed by GC/MS using a Hewlett-Packard 5890 GC, coupled with Hewlett-Packard 5971 Mass Selective Detector (HewlettPackard Inc., CA, USA). Typical reconstructed ion chromatogram (RIC) was obtained by running the sample with DB-5 capillary column (inner diameter $30 \mathrm{~m} \times 0.25 \mathrm{~mm}$, $0.25 \mu \mathrm{m}$ film-thickness; J \& W Scientific Inc., Folsom, CA) in the splitless mode with hydrogen as carrier $(60 \mathrm{~cm} / \mathrm{s}$ linear velocity) programmed from $100^{\circ} \mathrm{C}$ for $5 \mathrm{~min}$ to $250^{\circ} \mathrm{C}$ at $15^{\circ} \mathrm{C} / \mathrm{min}$ and held for $15 \mathrm{~min}$. Hydrocarbon analyses were replicated a total of three times with sets of independently prepared extracts for each strain.

\section{Open arena behavioural assays}

Walking responses and residence times of $T e$. podisi females to residues left by $E$. heros female adults were assayed in an open arena consisting of filter paper (number $1,24 \mathrm{~cm}$ diameter; Whatman, U.K.) where wasps could move in an unconstrained field. In the centre of the filter paper, a circular area $4.25 \mathrm{~cm}$ in diameter was either left untreated (control) or was exposed for $1 \mathrm{~h}$ to a single $E$. heros female adult constrained under a iron meshed cover ( $4 \mathrm{~cm}$ in diameter, $0.5 \mathrm{~cm}$ high, and $0.01 \mathrm{~cm} \mathrm{mesh}$ ), to ensure that the bugs were in continual tarsal contact with the treatment zone of the paper. To produce the 'footprints', an adult female E. heros was confined for $1 \mathrm{~h}$ under the wire cage placed overtop the test zone. Filter papers contaminated with faeces were not used for bioassays. Following application of the treatments, wasps were gently placed individually in the middle of the circular area. Continuous observation started immediately and stopped when the wasp flew from or walked out of the arena. Wasp responses to stink bug footprints (37 replicates/treatment) were compared with controls in which the test zone was left untreated.

The arena was lit from above and was observed using a video monitor (Sony SSM-14 N5E) connected with a monochrome CCD camera (Sony SPT M324CE) fitted with a 12.5-75-mm/F1.8 zoom lens (Alarmax Distributor Inc., Beltsville, USA). A video frame grabber (PC-Studio PCTV Pinnacle System-http://www.pinnaclesys.com) digitized analogue video signals from the camera, and data were processed using 'Xbug' Software (Colazza et al., 1999). We computed the arena residence time(s) (i.e. the time from when a wasp first entered the arena until it flew from or walked out of the arena). To quantify wasp's kinetic reactions (i.e. their adjustment in direction of the movement comparative to the distance moved), a novel index, named tortuosity index, as a measure for the wasp's linearity of movement, was applied. From the coordinates of the insect (sample rate $=15$ images $/ \mathrm{s}$ ), the tortuosity index was computed as:

Tortusity index $=1-m p / t$

where $m p$ is the projection of the track in general straight line of the plan, and $t l$ is the total length of the track. The value can range from 0 to 1 , with 0 indicating a completely linear tracking and 1 the maximum of tortuosity.

Freshly emerged $T e$. podisi females of both strains were kept for approximately $24 \mathrm{~h}$ with males, then they were individually isolated and supplied with a drop of pure honey. The females used in this experiment were 2-3 days old, and had not previously oviposited, nor had they been in contact with the host or its body, and they were used only once during the bioassays. All experiments were carried out from $09.00 \mathrm{~h}$ to $12.00 \mathrm{~h}$. The temperature in the bioassay room was kept at approximately $24^{\circ} \mathrm{C}$.

\section{Statistical analysis}

Data were tested for normality (Kolmogorov-Smirnov test) and, because there was no significant deviation from normal distribution, the variable values were then analysed with parametric tests ( $t$-test). All the data were analysed using the statistical software package, Statistica 5.1 (StatSoft, Inc. 1997). Fisher's exact probability test (StatSoft, 1997) was used to analyse the reciprocal and nonreciprocal (control) crosses between two strains of Te. podisi. The numbers of insects that recovered from the freezing experiments were expressed as percentages.

\section{Results and discussion}

\section{Crossing experiments}

The results showed that all crosses produced only males, indicating that successful mating between the Nearctic's and 
Neotropical Te. podisi strains did not occur. Moreover, the control crosses resulted in successful mating, and the sex ratios obtained from the control experiments were significantly different from each other (Table 1).

\section{Freezing experiments}

There was a large difference in cold tolerance individuals from the Nearctic's strain and wasps from the Neotropical strain (Fig. 1). The NA Te. podisi are able to recover after freezing periods of more than $120 \mathrm{~h}(>80 \%$ survival after 5 days at $-4{ }^{\circ} \mathrm{C}$ ), a trait which facilitates handling of this potential biological control agent.

\section{Cuticular hydrocarbons analysis}

Although there was little sex-specific difference in the cuticular hydrocarbon profiles within either Te. podisi strain, between strains the profiles were vastly different (Fig. 2). No obvious variation (qualitative/quantitative) was found among the three sets of cuticular extracts that were analysed for each strain. Because the prime goal of the cuticular hydrocarbon analysis was to distinguish two $T e$. podisi strains by hydrocarbon profile, we did not pursue chemical identification of individual compounds.

\section{Open arena behavioural assays}

After introduction into the control arena, females of both Te. podisi strains usually searched the arena in an apparently random pattern. The search patterns of the two strains in the absence of the host stimuli were not significantly different for both the parameters measured; arena resident time and tortuosity (Fig. 3A). By contrast, after introduction into a treated arena, TpSA females exhibited a distinctive searching behaviour in the vicinity of traces left by the $E$. heros female. Compared with the TpNA females, TpSA females spent significantly more time in the arena on which an E. heros ovipositional female walked than did TpNA females (Fig. 3B). The TpSA females turned back into the treated area when the edge of the zone was

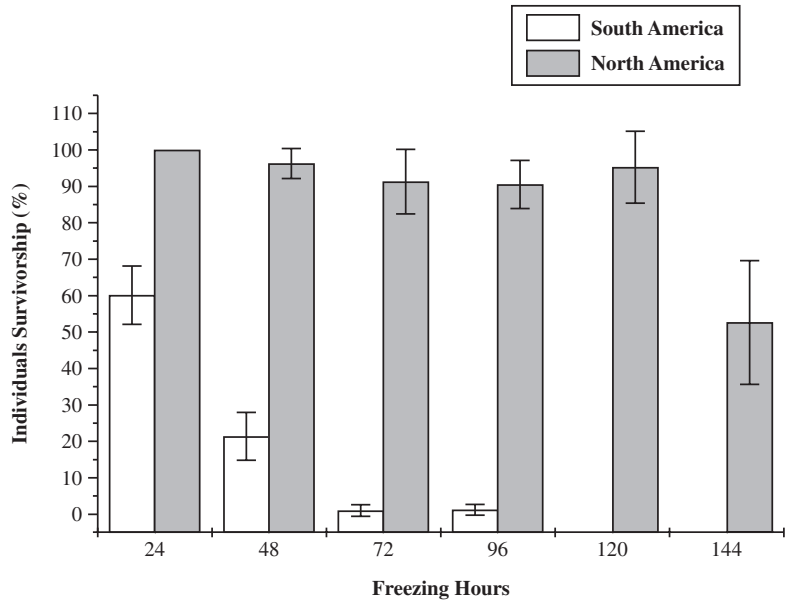

Fig. 1. Sub-freezing temperatures $\left(-4^{\circ} \mathrm{C}\right)$ cold tolerance $(\% \pm \mathrm{SE})$ of adult wasps from North (TpNA) and South (TpSA) American strains of Telenomus podisi for different time periods; $n=180$ (average number of individuals) and $n=10$, for the South American (TpSA) strain of Te. Podisi; $n=80$ (average number of individuals) and $n=6$, for the North American (TpNA) strain of Te. Podisi.

detected, changing their kinetic reaction as shown by the difference in the tortuosity index, which was significantly greater than that for TpNA females exposed to the same treatment (Fig. 3B).

Earlier research with Te. podisi in Brazil indicated that the South American strain of this egg parasitoid arrives in the vicinity of reproductive adults of Euschistus heros by orienting toward the allomone and/or pheromone compounds of the potential host (Borges etal., 1998). Here, we have shown that SA Te. podisi females specifically recognize traces left on the substrate by walking $E$. heros females and then intensively search the area of the 'footprints', apparently looking for an egg mass to parasitize. By contrast, the NA Te. podisi females are incapable of recognizing the footprints of $E$. heros females, despite the fact that these parasitoids were reared from eggs of E. heros. The influence of the host treated arena was significantly

Table 1. Reciprocal and nonreciprocal (control) crosses between two strains of Telenomus podisi.

\begin{tabular}{|c|c|c|c|c|c|c|c|}
\hline \multirow[b]{2}{*}{ Cross mating } & \multirow{2}{*}{$\begin{array}{l}\text { Total pair of } \\
\text { cross mating }\end{array}$} & \multicolumn{3}{|c|}{ Progeny } & \multirow{2}{*}{$\begin{array}{l}\text { Average number of offspring } \\
\text { produced by each female }\end{array}$} & \multirow{2}{*}{$\begin{array}{l}\text { Sex ratio } \\
(q / q+\hat{0})\end{array}$} & \multirow[b]{2}{*}{ Mean sex ratio } \\
\hline & & $\hat{0}$ & q & Total & & & \\
\hline o $\mathrm{SA} \times ð \mathbf{N A}$ & 11 & 157 & 0 & 157 & $14.3 \pm 3.0$ & 0 & 0 \\
\hline o $\mathrm{NA} \times \hat{0} \mathrm{SA}$ & 11 & 158 & 0 & 158 & $14.4 \pm 2.9$ & 0 & 0 \\
\hline $\operatorname{Egg}($ virgin $q \mathrm{SA}) \times \operatorname{Egg}($ mated $q \mathrm{NA})$ & 10 & 146 & 0 & 146 & $14.6 \pm 4.4$ & 0 & 0 \\
\hline $\operatorname{Egg}($ virgin $\$ \mathrm{NA}) \times \operatorname{Egg}($ mated $q \mathrm{SA})$ & 10 & 138 & 0 & 138 & $13.8 \pm 5.1$ & 0 & 0 \\
\hline o $\mathrm{SA} \times$ ô $\mathrm{SA}$ & 10 & 30 & 97 & 127 & $12.7 \pm 4.2$ & $0.7^{*}$ & $0.12 \pm 0.002 \mathrm{a}^{\mathrm{a} *}$ \\
\hline o $\mathrm{NA} \times \hat{o} \mathrm{NA}$ & 10 & 67 & 67 & 134 & $13.4 \pm 6.6$ & $0.5^{* *}$ & $0.21 \pm 0.003 b^{b * *}$ \\
\hline
\end{tabular}

*One female produced only male progeny.

**Four females produced only male progeny. Results are given as means \pm SD. Values in a column followed by the same letters are not significantly different at the 5\% level (Fisher's exact test). Sex ratios (expressed as male percentage) were arcsine-transformed before analysis and subsequently analysed by Fisher's exact probability test (StatSoft, 1997). 
Neotropical strain

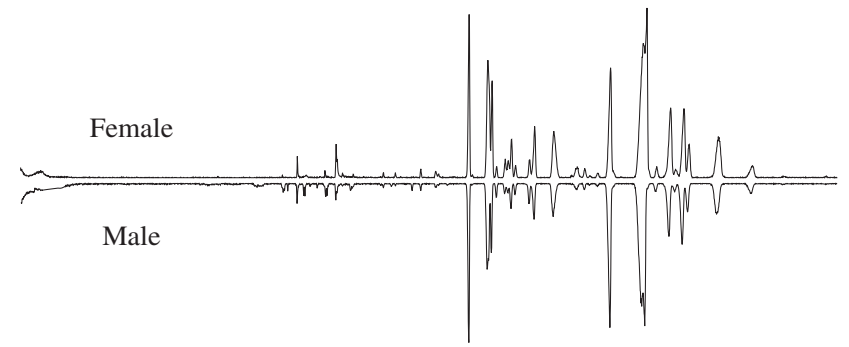

Fig. 2. Typical reconstructed ion chromatogram (RIC) obtained from cuticular hydrocarbon profiles showing the difference between parasitoid strains; the largest peak was automatically normalized to $100 \%, n=3$ (with sets of independently prepared extracts for each strain). (A) Chromatogram obtained from the South American (TpSA) strain of Telenomus podisi. (B) Chromatogram obtained from the North American (TpNA) strain of Te. podisi.

(a)

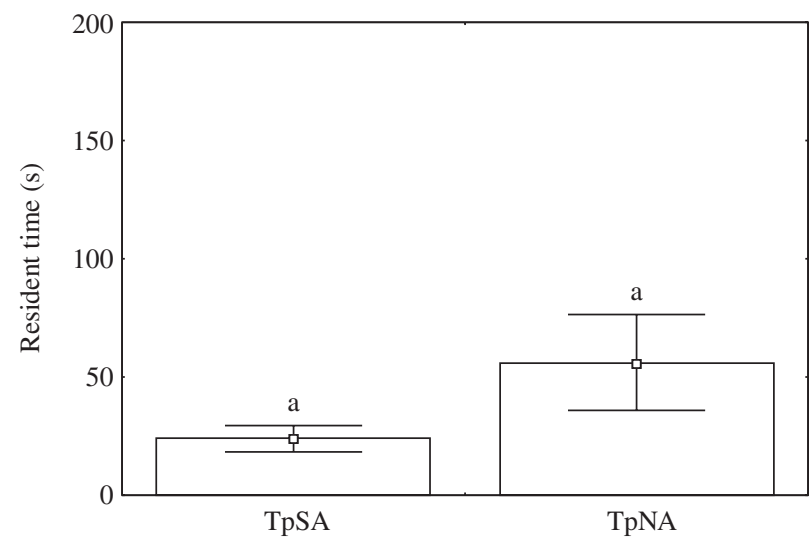

(b)

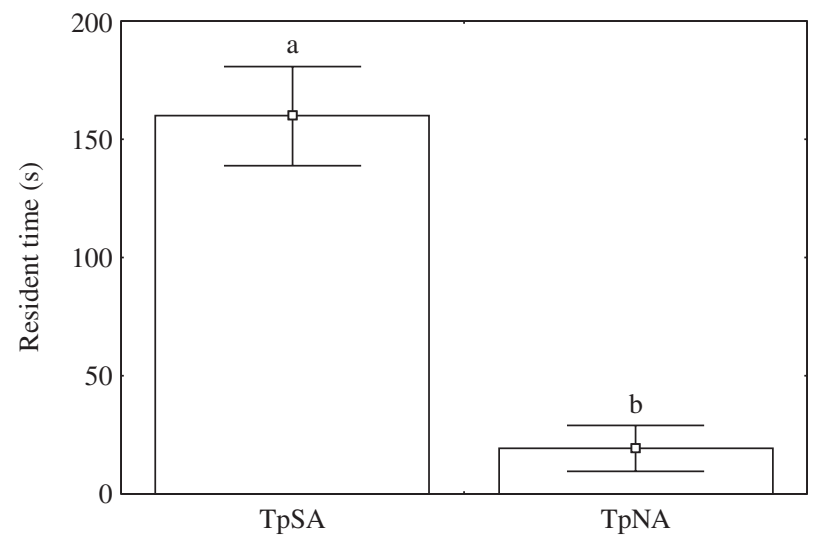

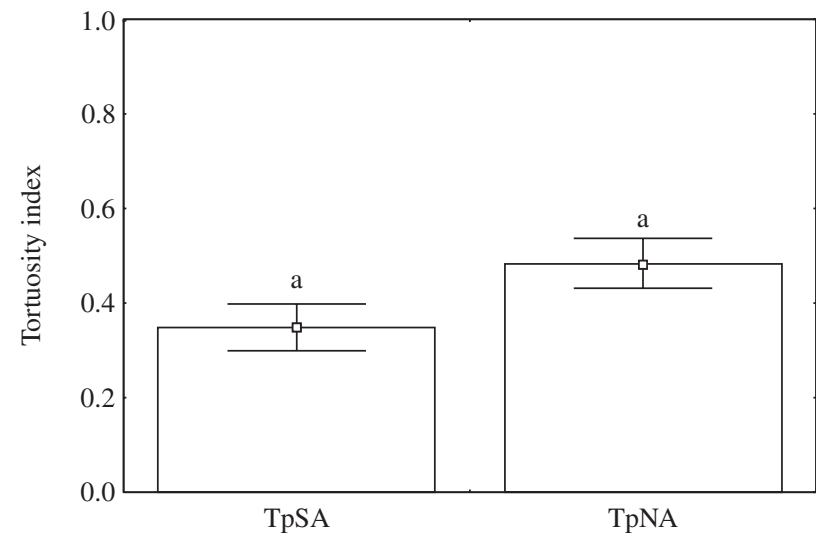

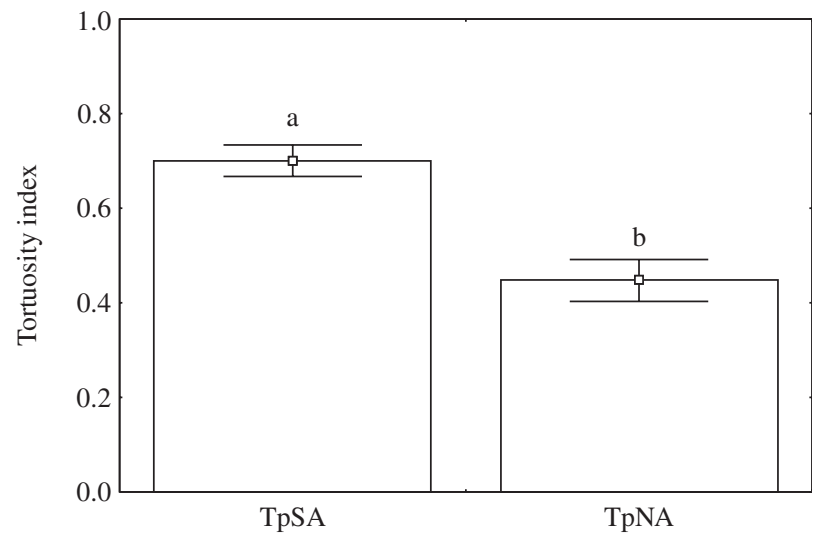

Fig. 3. Comparison of resident time and tortuosity index among the two different strains of Telenomus podisi when in contact with an untreated open arena (A), or when in contact with an open arena treated with the traces left by a mated female of Euschistus heros (B) (mean $\pm \mathrm{SE}$ ). Bars with the same letters are not significantly different at $P<0.01$ ( $t$-test $)(n=37)$. TpSA $=$ South American strain of Te. podisi; TpNA $=$ North American strain of Te. podisi . 
different when the two strains were compared. The Neotropical $T e$. podisi strain responded positively to the treated arena by displaying the characteristic searching behaviour of scelionid wasps, as described by Colazza et al. (1999) for $T r$. basalis searching for traces left by its host, $N$. viridula.

Cuticular hydrocarbons fulfil a multitude of roles and uses, including colony and nest mate recognition in social insects, discrimination of species, definition of larval karyotypes and, for taxonomic purposes, distinction between lineages (Anyanwu etal., 2001; Lahav et al., 2001; Akino et al., 2002; Nelson et al., 2002; Page et al., 2002; Quelle \& Strassmann, 2002; Ruther et al., 2002). Cuticular hydrocarbons also frequently play a role in mate discrimination in insects (Ishii et al., 2002). Consistent differences were found in cuticular hydrocarbons of the two closely related strains of Te. Podisi used here. Although there was little sexspecific difference within either strain, there was a great deal of divergence in the chemical profiles between the Te. podisi from North vs. South America.

Examination of a second physiological trait (cold tolerance) also revealed a dramatic discrepancy in the abilities of wasps from the two strains to withstand freezing. North American Te. podisi females are extremely cold tolerant ( $>80 \%$ survival after 5 days at $-4{ }^{\circ} \mathrm{C}$ ). Although this trait would facilitate tremendously the handling of this potential biological control agent, mass rearing and release of this strain in Brazil, or any other country where E. heros species are pests, is not worthwhile because females of NA strain are unable to track E. heros.

In summary, attempts to hybridize the North and South American strains of Te. podisi, in an effort to create a strain whose females are both cold-tolerant and efficient searchers, have repeatedly failed. This interstrain sterility, plus the major chemical, physiological and behavioural differences demonstrated here for the two strains, raises the distinct possibility or even likelihood that the so-called strains are actually separate species. Nevertheless, efforts are continuing to identify the footprint compounds from $E$. heros females that are recognized by South American Te. podisi female wasps, and to select a strain of the parasitoid combining cold tolerance and efficient host searching.

\section{Acknowledgements}

We are grateful to Ezio Peri (University of Palermo, Institute of Agricultural Entomology) for invaluable help with Xbug software and to Meiling Webb for technical support with insects during the tests. We are also grateful to Drs Carmen Pires and Eliana Fontes (Embrapa Genetic Resources and Biotechnology, Brazilia, DF, Brazil) for suggestions and reviewing the manuscript, and to Dr M. S. Loiácono (Faculdad de Ciencias Naturales and Museo de La Plata, Argentina) for the identification of the scelionid egg parasitoids.

\section{References}

Akino, T., Terayama, M., Wakamura, S. \& Yamaoka, R. (2002) Intraspecific variation of cuticular hydrocarbon composition in
Formica japonica Motschoulsky (Hymenoptera: Formicidae). Zoological Science, 19, 1155-1165.

Aldrich, J.R., Oliver, J.E., Lusby, W.R., Kochansky, J.P. \& Borges, M. (1994) Identification of male-specific volatiles from Nearctic and Neotropical stink bugs (Heteroptera: Pentatomidae). Journal of Chemical Ecology, 20, 1103-1111.

Aljanabi, S.M., Loiácono, M.S., Lourenço, R.T., Borges, M. \& Tigano, M.S. (1998) RAPD analysis revealing polymorphism in egg parasitoids of soybean stink bugs (Heteroptera: Pentatomidae). Anais da Sociedade Entomológica do Brasil, 27, 345-352.

Anyanwu, G.I., Davies, D.H., Molyneux, D.H. \& Priestman, A. (2001) Cuticular-hydrocarbon discrimination between Anopheles gambiae s.s. and An. arabiensis larval karyotypes. Annals of Tropical Medicine and Parasitology, 95, 843-852.

Boo, K.S. \& Yang, J.P. (2000) Kairomones used by Trichogramma chilonis to find Helicoverpa assulta eggs. Journal of Chemical Ecology, 26, 359-376.

Borges, M. \& Aldrich, J.R. (1994) Attractant pheromone for Nearctic stink bug, Euschistus obscurus (Heteroptera: Pentatomidae): insight into a Neotropical relative. Journal of Chemical Ecology, 20, 1095-1102.

Borges, M., Schmidt, F.V.G., Sujii, E.R., Medeiros, M.A., Mori, K., Zarbin, P.H.G. \& Ferreira, J.T.B. (1998) Field responses of stink bugs to the natural and synthetic pheromone of the Neotropical brown stink bug, Euschistus heros, (Heteroptera: Pentatomidae). Physiological Entomology, 23, 101-106.

Borges, M., Costa, M.L.M., Sujii, E.R., Cavalcanti, M., das, G., Redígolo, G.F., Resck, I.S. \& Vilela, E.F. (1999) Semiochemical and physical stimuli involved in host recognition by Telenomus podisi (Hymenoptera: Scelionidae) toward Euschistus heros (Heteroptera: Pentatomidae). Physiological Entomology, 24, 227-233.

Colazza, S. \& Rosi, M.C. (2001) Differences in the searching behavior of two strains of the egg parasitoid Telenomus busseolae (Hymenoptera: Scelionidae). European Journal of Entomology, 98, 47-52.

Colazza, S., Salermo, G. \& Wajnberg, E. (1999) Volatile and contact chemicals released by Nezara viridula (Heteroptera: Pentatomidae) have a kairomonal effect on the egg parasitoid Trissolcus basalis (Hymenoptera: Scelionidae). Biological Control, 16, 310-317.

Ehler, L.E. (2000) Farmscape ecology of stink bugs in Northern California. Thomas Say Publications: Memoirs. Entomological Society of America, Lanham, MD. 59p.

Ishii, K., Hirai, Y., Katagiri, C. \& Kimura, M.T. (2002) Mate discrimination and cuticular hydrocarbons in Drosophila elegans and D. gunungcola. Zoological Science, 19, 1191-1196.

Johnson, N.F. (1984) Systematics of neartic Telenomus: classification and revisions of the podisi and phymatae species groups (Hymenoptera: Scelionidae). Bulletin of the Ohio Biology Survey, 6, 113p.

Johnson, N.F. (1992) Catalog of world species of Proctotrupoidea, exclusive of Platygastridae (Hymenoptera). Memoirs of the American Entomological Institute, 51, 825p.

Lahav, S., Soroker, V., Vander Meer, R.K. \& Hefetz, A. (2001) Segregation of a colony odor in the desert ant Cataglyphis niger. Journal of Chemical Ecology, 27, 927-943.

Leal, W.S., Higuchi, H., Mizutani, N., Nakamori, H., Kadosawa, T. \& Ono, M. (1995) Multifunctional communication in Riptortus clavatus (Heteroptera: Alydidae): conspecific nymphs and egg parasitoid Ooencyrtus nezarae use the same adult attractant pheromone as chemical cue. Journal of Chemical Ecology, 21, 973-985.

Lewis, W.J., Vet, L.E.M., Tumlinson, J.H., van Lenteren, J.C. \& Papaj, D.R. (1990) Variation in parasitoid foraging behaviour: essential element of a sound biological control theory. Environmental Entomology, 19, 1183-1193. 
Mattiacci, L., Vinson, S.B., Williams, H.J., Aldrich, J.R. \& Bin, F. (1993) A long-range attractant kairomone for egg parasitoid Trissolcus basalis, isolated from defensive secretion of its host, Nezara viridula. Journal of Chemical Ecology, 19, 1167-1181.

Nelson, D.R., Olson, D.L. \& Fatland, C.L. (2002) Cuticular hydrocarbons of the flea beetles, Aphthona lacertosa and Aphthona nigriscutis, biocontrol agents for leafy spurge (Euphorbia esula). Comparative Biochemistry and Physiology B: Biochemistry and Molecular Biology, 133, 337-350.

Page, M., Nelson, L.J., Forschler, B.T. \& Haverty, M.I. (2002) Cuticular hydrocarbons suggest three lineages in Reticulitermes (Isoptera: Rhinotermitidae) from North America. Comparative Biochemistry and Physiology B: Biochemistry and Molecular Biology, 131, 305-324.

Parra, J.R.P., Botelho, P.S.M., Corrêa-Ferreira, B.S. \& Bento, J.M. (eds) (2002) O Futuro Do Controle Biológico, pp. 582-587. Controle Biológico no Brasil, Editora Manole Ltda, Brazil.
Quelle, D.C. \& Strassmann, J.E. (2002) The many selves of social insects. Science, 296, 311-313.

Ruberson, J.R., Tauber, M.J. \& Tauber, C.A. (1989) Intraspecific variability in hymenopteran parasitoids: comparative studies of two biotypes of the egg parasitoid Edovum puttleri (Hymenoptera: Eulophidae). Journal of the Kansas Entomological Society, 62, 189-202.

Ruther, J., Sieben, S. \& Schricher, B. (2002) Nestmate recognition in social wasps: manipulation of hydrocarbon profiles induces aggression in the European hornet. Naturwissenschaften, 89, 111-114.

Statsoft Italia (1997) Statistica per Windows. Users manual. Statsoft Italia s.r.l., Vigonza, Italy.

Vinson, S.B. (1998) The general host selection behavior of parasitoid Hymenoptera and a comparison of initial strategies utilized by larvaphagous and oophagous species. Biological Control, 11, 79-96.

Accepted 8 July 2003 